\title{
RITUAL ISLAM KEJAWEN ANAK PUTU KI BONOKELING
}

\author{
Wita Widyandini, Atik Suprapti, dan R. Siti Rukayah \\ Universitas Diponegoro Semarang \\ Jl. Prof. Sudarso Tembalang Semarang 50275 \\ E-mail: witadidyandini@yahoo.co.id \\ HP. +62-8122708723
}

Abstract: Bonokeling society that lives in Pekuncen village, Jatilawang subdistrict, Banyumas regency, are the adherents of "Islam Blangkon" or known as "Islam Kejawen". Ancestral figure who became a role model and whom they ask for something is Bonokeling. As the adherents of Kejawen, Bonokeling people has many ritual beliefs, regularly scheduled and did not. This research aims to find the pattern of rituals procession of Bonokeling people and its influence on spatial settlement of the Bonokeling society.

Abstrak: Penelitian ini bertujuan untuk menemukan pola dari prosesi ritual masyarakat Bonokeling dan pengaruhnya terhadap tata spasial pemukiman dari situs Bonokeling. Dalam kepercayaan Kejawen, Bonokeling telah menjadi ritual kepercayaan, baik yang terjadwal maupun tidak. Situs Bonokeling terletak di Desa Pakuncen, Kecamatan Jatilawang, Kabupaten Banyumas, yang merupakan pusat dari kepercayaan "Islam Blangkon" atau dikenal dengan sebutan "Islam Kejawen". Dari penelitian diperoleh hasil bahwa prosesi upacara ritual turut mempengaruhi pola tata spasial permukiman masyarakat Bonokeling di Banyumas untuk mendekatkan diri kepada Tuhan Yang Maha Esa.

Kata Kunci: ritual, spasial, Bonokeling settlement, Islam.

\section{A. Pendahuluan}

Kabupaten Banyumas memiliki banyak peninggalan sejarah dan kebudayaan, salah satunya adalah Situs Bonokeling yang terletak di Desa Pekuncen, Kecamatan Jatilawang. Walaupun situs ini telah berusia rat usan tahun, namun eksistensinya masih bertahan hingga saat ini. Situs Bonokeling memiliki tiga wujud budaya yang tidak dijumpai di tempat lain, yaitu: Islam Kejawen, ritual upacara kepercayaan, dan permukiman dengan pola tata ruang tertentu. 
Sebagai penganut Islam Kejawen, masyarakat Bonokeling ini memiliki banyak ritual kepercayaan, baik yang terjadwal maupun yang tidak terjadwal. Untuk melaksanakan semua aktivitas ritual kepercayaan tersebut, masyarakat Bonokeling melakukannya pada Situs Bonokeling yang terletak di permukiman Bonokeling. Ada dugaan bahwa tata spasial (ruang) pada permukiman Bonokeling dipengaruhi oleh ritual upacara kepercayaan masyarakatnya.

Untuk itu dilakukan penelitian dengan tujuan menemukan pola prosesi upacara ritual kepercayaan masyarakat Bonokeling dan pengaruhnya terhadap tata spasial permukiman masyarakat Bonokeling. Oleh karena penelitian bertujuan menemukan atau mengeksplorasi suatu fenomena, maka metode penelitian yang digunakan adalah metode kualitatif dengan menggunakan analisis deskriptif. Tulisan ini dititikberatkan pada pola prosesi upacara ritual kepercayaan dan pengaruhnya terhadap tata spasial permukiman.

\section{B. Budaya dan Tata Ruang Permukiman}

Orang Jawa adalah orang yang religius dan berketuhanan. Sejak masa prasejarah, mereka telah memiliki kepercayaan animisme, yaitu suatu kepercayaan tentang adanya roh atau jiwa-jiwa pada benda, tumbuhan, hewan, dan pada manusia sendiri. Kepercayaan seperti itu adalah agama pertama mereka (Ismawati dalam Amin, 2000: 6). Ketika Islam masuk ke Jawa, agama Hindu, Buddha, dan kepercayaan asli yang berdasarkan animisme dan dinamisme telah mengakar di kalangan masyarakat Jawa sehingga kemudian terjadi pergumulan antara Islam dan kepercayaan-kepercayaan lain yang sudah ada sebelumnya. Akibatnya, muncul dua kelompok, yaitu kelompok yang menerima Islam secara total, dan kelompok yang menerima Islam tetapi belum dapat melupakan ajaranajaran lama (Amin, 2000: 94). Menurut Yana (2010: 16), kelompok yang menerima Islam secara total dan berusaha untuk hidup menurut ajaran Islam disebut dengan kelompok Santri, sedangkan kelompok yang menerima Islam tetapi belum dapat melupakan ajaran-ajaran lama dan cara hidupnya ditentukan oleh tradisi Jawa pra-Islam dikenal dengan nama kelompok Kejawen.

Kata "Kejawen" berasal dari kata Jawa, sebagai kata benda yang memiliki arti dalam bahasa Indonesia yaitu segala yang berhubungan dengan adat dan kepercayaan Jawa (Yana, 2010: 109). Kejawen merupakan campuran (sinkretisme) kebudayaan Jawa dengan agama pendatang, yaitu Hindu, Buddha, Islam, dan Kristen (Ridwan, dkk, 2008: 48). Di antara percampuran tersebut yang paling dominan adalah agama Islam. Jadi, Islam Kejawen adalah model keberagamaan yang merupakan perpaduan antara Islam dengan budaya atau tradisi Jawa, sehingga menampilkan Islam yang berwatak dan bergaya Jawa. 
Ritual atau upacara pokok dalam Kejawen adalah Slametan atau Kenduri (Yana, 2010: 118). Slametan ini dapat berupa upacara atau ritual kepercayaan. Slametan bagi masyarakat Jawa tidak hanya sebagai wujud ritual religius saja, tapi Slametan juga untuk merekatkan kerukunan dan keselarasan, untuk mewujudkan ketenteraman dan kekuatan gotong-royong (Widagdho dalam Amin, 2000: 74). Melaksanakan upacara ritual merupakan sebagian ekspresi budaya dari masyarakat Kejawen. Kebudayaan menurut Koentjaraningrat (1989: 180) adalah sebuah sistem gagasan, tindakan dan hasil karya yang dihasilkan dalam rangka kehidupan manusia dan dijadikan hak milik manusia melalui proses belajar. Dengan pikiran-pikiran mereka melakukan tindakan atau aktivitas, dan dengan perpaduan keduanya, mereka menghasilkan benda-benda kebudayaan fisiknya (Koentjaraningrat, 1982: 7). Benda-benda kebudayaan fisik termasuk di dalamnya adalah permukiman dan bangunan tradisional.

Menurut Rapoport dalam Kent (1990: 10-11), budaya yang dimiliki oleh seorang manusia atau sekelompok manusia akan menghasilkan suatu pandangan hidup. Dengan pandangan hidupnya ini, mereka kemudian merumuskan nilai-nilai hidup yang disepakati dan diyakini bersama. Nilai-nilai hidup ini lalu mereka laksanakan dalam gaya hidup sehari-hari dalam bentuk aktivitas atau kegiatan. Aktivitas atau kegiatan yang berlangsung kemudian ditampung dalam suatu wadah yang berupa ruang (space) yang saling berhubungan satu dengan lainnya dan membentuk suatu pola tata ruang tersendiri. Dalam hal ini, dapat disimpulkan bahwa budaya seorang manusia atau sekelompok manusia menentukan aktivitas maupun pola tata ruang (dalam hal ini adalah tata ruang permukiman) tempat aktivitas tersebut berlangsung.

Pada permukiman juga terbentuk suatu pola sirkulasi yang dibangun oleh perilaku masyarakatnya. Sirkulasi dapat diartikan sebagai "tali" yang mengikat ruang-ruang suatu bangunan atau suatu deretan ruang-ruang dalam maupun luar, menjadi saling berhubungan (Ching, 1993: 246). Untuk permukiman tradisional, pola sirkulasi yang terbentuk berkaitan dengan hubungan antara manusia-Tuhan, manusia-alam, manusia-masyarakat, dan manusia-pribadi yang terwujud dalam aktivitas ritual, produksi, sosial, dan rutin sehari-hari (Salura, 2008: 61).

\section{Ritual Islam BLangKon Bonokeling}

Aktivitas ritual kepercayaan masyarakat Bonokeling dipusatkan di Bale Badung yang terdiri dari Pasemuan dan Bale Malang. Khusus untuk upacara Unggah-Unggahan, Turunan, dan Perlon Rikat dilakukan pula ritual ziarah ke Makam Bonokeling. Sedangkan untuk upacara Sedekah Bumi dan Kupatan 
Senin Paing tidak ada ritual ziarah ke makam Bonokeling.

Semua upacara ritual kepercayaan baik yang yang terjadwal seperti Unggah-Unggahan, Turunan, Perlon Rikat, Sedekah Bumi, dan Kupatan Senin Paing maupun yang tidak terjadwal seperti upacara Mlebu, Puput Puser, dan Nikah dipimpin oleh Kyai Kunci atau yang biasa dipanggil dengan nama Kuncen.

Sebagai masyarakat Kejawen, masyarakat Bonokeling banyak melakukan ritual kepercayaan. Untuk ritual kepercayaan yang sifatnya terjadwal memiliki urutan-urutan prosesi tertentu (lihat tabel 1). Dari urutan prosesi upacara akan ditemukan elemen tata ruang yang digunakan pada upacara tersebut. Selanjutnya dianalisis untuk menemukan ada tidaknya pengaruh upacara ritual terhadap pola tata ruang permukiman Bonokeling.

Tabel 1. Prosesi Upacara Ritual Masyarakat Bonokeling (Sumber: Widyandini, 2013).

\begin{tabular}{|c|c|c|c|}
\hline No & $\begin{array}{l}\text { Nama } \\
\text { Ritual }\end{array}$ & Kegiatan yang Dilakukan & $\begin{array}{c}\text { Elemen Tata } \\
\text { Ruang }\end{array}$ \\
\hline 1. & $\begin{array}{l}\text { Unggah- } \\
\text { Unggahan }\end{array}$ & $\begin{array}{l}\text { - Rabu: prosesi diawali dengan melakukan memet } \\
\text { godhong \& njenang } \\
\text { Kamis: anak putu manca kabupaten mulai } \\
\text { berdatangan, berjalan kaki menuju rumah } \\
\text { Bedogol masing-masing. Kaum laki-laki } \\
\text { memanggul ternak seperti kambing dan hasil } \\
\text { bumi, sementara kaum perempuan membawa } \\
\text { bakul berisi beras, lauk pauk dan jajan pasar. } \\
\text { Jumat: dari rumah Bedogol masing-masing, para } \\
\text { anak putu kemudian berkumpul di Pelataran. } \\
\text { Beras, lauk pauk dan jajanan pasar dimasak di } \\
\text { Crabakan dan sebagian di Bale Malang, setelah } \\
\text { matang diantar ke Bale Mangu dan Pasemuan } \\
\text { - Anak putu ziarah dan Donga ke makam } \\
\text { Bonokeling dengan dipimpin oleh Kyai Kunci. } \\
\text { Setelah ziarah dilanjutkan jamuan di Bale Mangu } \\
\text { dan Pasemuan. }\end{array}$ & \begin{tabular}{|l} 
- Pelataran \\
Bale \\
Malang \\
Pasemuan \\
Crabakan \\
Bale \\
Mangu \\
Makam
\end{tabular} \\
\hline 2. & Turunan & $\begin{array}{l}\text { - Rabu: prosesi diawali dengan melakukan memet } \\
\text { godhong \& njenang. } \\
\text { - Kamis pagi: melakukan Rikat (membersihkan } \\
\text { makam Bonokeling). } \\
\text { - Anak putu manca kabupaten pun mulai } \\
\text { berdatangan. }\end{array}$ & $\begin{array}{l}\text { - Pelataran } \\
\text { - Pasemuan } \\
\text { - Crabakan } \\
\text { - Makam }\end{array}$ \\
\hline
\end{tabular}


Wita W., dkk.: Ritual Islam Kejawen Anak Putu Ki Bonokeling (hal. 191-200)

\begin{tabular}{|c|c|c|c|}
\hline No & $\begin{array}{l}\text { Nama } \\
\text { Ritual }\end{array}$ & Kegiatan yang Dilakukan & $\begin{array}{c}\text { Elemen Tata } \\
\text { Ruang }\end{array}$ \\
\hline & & $\begin{array}{l}\text { Rabu: prosesi diawali dengan melakukan memet } \\
\text { godhong \& njenang. } \\
\text { Kamis pagi: melakukan Rikat (membersihkan } \\
\text { makam Bonokeling). } \\
\text { Anak putu manca kabupaten pun mulai } \\
\text { berdatangan. }\end{array}$ & \\
\hline 3. & $\begin{array}{l}\text { Perlon } \\
\text { Rikat }\end{array}$ & $\begin{array}{l}\text { Kamis malam: anak putu berkumpul di Bedogol } \\
\text { masing-masing melakukan Muji hingga pukul } \\
24.00 \\
\text { Jumat: anak putu berkumpul di Pelataran, } \\
\text { kemudian melakukan Rikat dimulai dari makam } \\
\text { Bonokeling terus ke makam pengikutnya } \\
\text { Kemudian menuju Pasemuan untuk melakukan } \\
\text { slametan. Slametan dimulai dengan Mujudaken } \\
\text { lalu Donga dengan dipimpin Kyai Kunci, } \\
\text { dilanjutkan dengan jamuan } \\
\text { Wangsul }\end{array}$ & $\begin{array}{l}\text { - Pelataran } \\
\text { - Pasemuan } \\
\text { - Makam }\end{array}$ \\
\hline 4. & $\begin{array}{l}\text { Sedekah } \\
\text { Bumi }\end{array}$ & $\begin{array}{l}\text { Selasa: Anak putu memasak di rumah masing- } \\
\text { masing, setelah matang masakan dikumpulkan ke } \\
\text { Bale Malang untuk kemudian dibawa ke Balai } \\
\text { Desa bersama-sama. } \\
\text { Anak putu berkumpul di Pelataran untuk } \\
\text { melaksanakan slametan. Slametan diawali } \\
\text { dengan Mujudaken lalu Donga dipimpin oleh } \\
\text { Kyai Kunci } \\
\text { Kemudian melaksanakan ritual Mendhem } \\
\text { (menanam) sesaji di pertigaan Desa Pekuncen. } \\
\text { Selesai mendhem, menuju Balai Desa dan } \\
\text { melakukan Kepungan lalu sawuran hasil } \\
\text { masakan diikuti oleh seluruh warga Desa } \\
\text { Pekuncen } \\
\text { Wangsul } \\
\text { Selasa malam: Ruwat Bumi dengan Wayangan } \\
\text { (tapi tidak wajib) }\end{array}$ & $\begin{array}{l}\text { Pelataran } \\
\text { Bale } \\
\text { Malang } \\
\text { Pertigaan } \\
\text { Desa } \\
\text { Pekuncen } \\
\text { Balai Desa }\end{array}$ \\
\hline 5. & $\begin{array}{l}\text { Kupatan } \\
\text { Senin } \\
\text { Paing }\end{array}$ & $\begin{array}{l}\text { Anak putu berkumpul di Bedogol masing-masing. } \\
\text { Makanan berupa kupat slamet dibawa ke Bale } \\
\text { Malang. } \\
\text { Menuju Mundu untuk melakukan slametan. } \\
\text { Acara slametan dimulai dengan Mujudaken lalu } \\
\text { Donga dipimpin oleh Kyai Kunci } \\
\text { Wangsul }\end{array}$ & $\begin{array}{l}\text { Bale } \\
\text { Malang } \\
\text { - Mundu } \\
\text { - Ma }\end{array}$ \\
\hline
\end{tabular}

Dari tabel tersebut, dipahami bahwa arah dan tujuan dari ritual untuk keselamatan melalui doa yang dipanjatkan kepada Tuhan Yang Maha Esa. Pola ini mengajarkan kepada manusia agar senantiasa taat dan patuh kepada sang 
Pencipta. Filosofi ini menegaskan bahwa usaha yang dilakukan oleh manusia tidak akan terjadi, tanpa ada ketetapan dari Tuhan.

\section{Ritual UngGaH-UngGaH}

Ritual Unggah-Unggahan dilaksanakan pada bulan Sadran menjelang puasa Ramadhan. Tujuan dari ritual Unggah-Unggahan ini adalah untuk menyambut musim menanam padi atau yang dikenal dengan istilah munggah, sehingga ritualnya dikenal dengan nama Unggah-Unggahan. Sirkulasi para Bedogol dan anak putu Bonokeling menuju ke Bale Malang tempat diselenggarakannya ritual memiliki aturan tersendiri. Aturan ini berdasarkan pada falsafah masyarakat Bonokeling yang mengumpamakan para Bedogol dan Kyai Kunci sebagai Pandawa dan Kresna.

Bedogol Padasumadi merupakan perwujudan dari Werkudara, Bedogol Wiryapada perwujudan Kresna, Bedogol Padawireja perwujudan Arjuna, Kyai Kunci Kartasari perwujudan Yudhistira, Bedogol Martasari perwujudan Nakula, dan Bedogol Martaleksana perwujudan Sadewa. Untuk itu, setiap kali ada upacara ritual maka Bedogol Padasumadi harus yang menjemput Bedogol Wiryapada, Bedogol Padawireja harus yang menjemput Kyai Kunci Kartasari, dan Bedogol Martaleksana harus yang menjemput "kakak kembar" nya Bedogol Martasari.

Sirkulasi ritual diawali dari Kongsen masing-masing Bedogol dan anak putu nya menuju ke Pelataran. Kaum pria memanggul ternak dan hasil bumi dan kaum perempuan membawa bakul berisi makanan. Makanan yang telah matang diletakan di Bale Malang, sedangkan yang masih mentah diletakan di Crabakan samping Bale Malang untuk dimasak bersama-sama.

Ritual ziarah Mbah Bonokeling diawali dari depan rumah Kyai Kunci selaku pemimpin upacara ritual. Dari depan rumah Kyai Kunci menuju ke arah Barat ke arah rumah Bedogol Martasari, lalu belok kanan menuju makam melalui Lurung. Dari Lurung terus ke Utara ke arah makam.

Sesampainya di komplek makam Bonokeling, peserta ziarah bersuci (membasuh muka serta mencuci tangan dan kaki) di tempat persucian. Setelah bersuci, para peserta satu persatu memasuki cungkup makam Bonokeling. Peserta putri terlebih dahulu yang ziarah ke makam, setelah para peserta putri selesai ziarah baru dilanjutkan para peserta putra.

Para estri (ibu-ibu) yang bertugas memasak, akan memasak di Crabakan. Lalu setelah matang dikirim ke Pasemuan dan ke Bale Mangu di kompleks makam. Setelah ritual ziarah selesai, peserta ritual kemudian melakukan jamuan 
Wita W., dkk.: Ritual Islam Kejawen Anak Putu Ki Bonokeling (hal. 191-200)

makan-makan yang telah disediakan di Bale Mangu dan Pasemuan. Setelah itu acara selesai, dan peserta dapat kembali ke rumah masing- masing.

\section{E. Ritual Turunan}

Ritual Turunan merupakan ritual akan memanen padi, tapi karena dilaksanakan setelah puasa Ramadhan maka ritual Turunan ini disebut juga dengan Rampung Puasa. Sirkulasi diawali dari Kongsen masing-masing Bedogol dan anak putu nya menuju ke Pelataran. Setelah semua peserta kumpul, mereka selanjutnya melakukan rikat atau bersih-bersih sekitar permukiman, makam, termasuk ndandani gethek (mengganti pagar bambu) sekeliling pemukiman.

Kemudian para Bedogol dan anak putu melakukan ziarah ke makam Bonokeling. Ritual ziarah Mbah Bonokeling diawali dari depan rumah Kyai Kunci. Dari depan rumah Kyai Kunci menuju ke arah Barat ke arah rumah Bedogol Martasari lalu belok kanan menuju makam melalui Lurung. Dari Lurung terus ke Utara ke arah makam.

Para estri yang bert ugas memasak, akan memasak di Crabakan. Lalu setelah matang dikirim ke Pasemuan. Setelah melakukan ziarah, para peserta ritual Turunan menuju Pasemuan untuk melakukan Donga (doa-doa) dan jamuan. Setelah Donga dan jamuan, acara selesai dan peserta kembali ke rumah masingmasing.

\section{F. Ritual Perlon Rikat}

Ritual Perlon Rikat ini adalah ritual memberikan Donga/doa kepada leluhur masyarakat Bonokeling. Prosesi diawali dengan melakukan Rikat yaitu membersihkan lingkungan, ndandani gethek/memperbaiki pagar bambu yang mengelilingi permukiman, serta membersihkan makam. Sirkulasi diawali dari Kongsen masing-masing Bedogol dan anak putu-nya menuju ke tempat ritual Pasemuan. Mereka kemudian berkumpul di Pelataran. Masakan dan sesaji yang sudah matang diletakan di Pasemuan. Sesaji berupa hewan sembelihan namun bila terpaksa tidak ada, dapat menggunakan tumpeng.

Kemudian para Bedogol dengan diikuti anak putu nya melakukan ziarah ke makam Bonokeling. Ritual ziarah Mbah Bonokeling diawali dari depan rumah Kyai Kunci. Dari depan rumah Kyai Kunci menuju ke arah Barat ke arah rumah Bedogol Martasari lalu belok kanan menuju makam melalui Lurung. Dari Lurung terus ke Utara ke arah makam. Setelah melakukan ziarah para peserta ritual Perlon Rikat melanjutkan ritual ke Pasemuan untuk melakukan Donga dan jamuan. Setelah Donga dan jamuan, acara selesai dan peserta kembali ke rumah masing-masing. 


\section{G. Ritual Sedekah Bumi}

Ritual Sedekah Bumi merupakan ritual pemberian sesaji kepada Yang Kuasa karena telah memberikan banyak rezeki kepada masyarakat Bonokeling dan masyarakat Desa Pekuncen pada umumnya. Ritual ini diikuti oleh seluruh masyarakat Desa Pekuncen baik yang masih keturunan Bonokeling maupun yang bukan keturunan Bonokeling. Sirkulasi diawali dari Kongsen masingmasing Bedogol dan anak putu-nya menuju Pelataran. Masakan yang sudah matang dikumpulkan di Bale Malang untuk selanjutnya dibawa ke Balai Desa bersama-sama.

Selanjutnya, dari Bale Malang ke arah Barat ke arah rumah Bedogol Martasari dengan dipimpin Kyai Kunci. Lalu belok ke arah Utara melalui Lurung. Di perempatan jalan desa kemudian belok kanan kearah Timur menuju ke pertigaan Desa Pekuncen. Kemudian dilaksanakan ritual mendhem atau menguburkan sesaji berupa kepala hewan sembelihan yang dibungkus kain putih di pertigaan Desa Pekuncen, setelah sebelumnya dibacakan doa-doa. Selanjutnya mereka menuju ke Balai Desa untuk melakukan ritual Sawuran (lempar-lemparan makanan) dengan sesama warga Desa Pekuncen. Malam harinya dilaksanakan Wayangan, tetapi acara ini tidak wajib ada.

\section{H. Ritual Kupatan Senin Pahing}

Ritual Kupatan dilaksanakan setiap Senin Pahing, mulai pukul 07.00 12.00 WIB. Ritual berupa Donga dengan sesaji yang berupa kupat slamet. Sirkulasi diawali dari Kongsen masing-masing Bedogol dan anak putu nya menuju Bale Malang dengan membawa kupat slamet. Dari Bale Malang peserta menuju ke arah Barat ke arah rumah Bedogol Martasari, lalu belok kiri ke arah Selatan menyusuri Lurung hingga sampai ke Mundu. Kemudian dilakukan Donga dengan cara lesehan. Akan tetapi, bila hujan, acara tetap dilaksanakan di Bale Malang.

\section{Simpulan}

Dari pembahasan, dapat disimpulkan beberapa hal berikut ini. Pertama, semua ritual diawali dari Kongsen (rumah dinas) Bedogol, sebelum berkumpul dengan anak putu dari Bedogol-Bedogol lainnya di Pelataran. Jadi di sini Pelataran berfungsi sebagai tempat berkumpul anak putu sebelum melaksanakan semua kegiatan ritual. Semua ritual doa-doa atau memuji dilaksanakan di Pasemuan atau Bale Malang.

Kedua, semua ritual untuk leluhur diakhiri dengan ziarah makam. Makam menjadi ruang yang dituju paling akhir, hal ini menjadikan makam sebagai 
sesuatu yang paling tinggi nilainya atau dapat dikatakan memiliki hirarki yang paling tinggi. Apabila dalam permukiman Islam santri, masjid yang menjadi pusat lingkungannya, maka dalam permukiman masyarakat Bonokeling yang merupakan penganut Islam Kejawen, yang berfungsi sebagai pusat lingkungan adalah Pasemuan dan Bale Malang.

Ketiga, Pasemuan dan Bale Malang sebagai pusat lingkungan permukiman Bonokeling terletak di bagian paling depan (sebelah utara) dari permukiman. Ini selain mempermudah akses masyarakat Bonokeling pada saat upacara ritual, juga menjadikan Pasemuan dan Bale Malang menjadi semacam landmark bagi permukiman Bonokeling di Banyumas. Dari uraian tersebut, dapat dipahami bahwa prosesi upacara ritual turut mempengaruhi pola tata spasial permukiman masyarakat Bonokeling di Banyumas untuk mendekatkan diri kepada Tuhan Yang Maha Esa.

\section{Daftar Pustaka}

Amin, Darori. 2000. "Sinkretisme dalam Masyarakat Jawa" dalam Amin, Darori (Ed.). Islam dan Kebudayaan Jawa. Yogyakarta: Gama Media.

Ching, Francis DK. 1993. Arsitektur: Bentuk, Ruang, dan Susunannya (Terj.). Jakarta: Erlangga.

Ismawati. 2000. "Budaya dan Kepercayaan Jawa Masa Pra-Islam" dalam Amin, Darori (Ed.). Islam dan Kebudayaan Jawa. Yogyakarta: Gama Media. Koentjaraningrat.1982. Kebudayaan, Mentalitas, dan Pembangunan. Jakarta: Gramedia.

1989. Pengantar Ilmu Antropologi. Jakarta: Aksara Baru.

Rapoport, Amos. 1990. "Systems of activities and systems of settings" dalam

Kent, Susan (Ed.). Domestic Architecture and The Use of Space: An Interdisciplinary Cross-Cultural Study. Cambridge: Cambridge University Press.

Ridwan, dkk. 2008. Islam Kejawen: Sistem Keyakinan dan Ritual Anak-Cucu Ki Bonokeling. Purwokerto: STAIN Purwokerto Press dan Unggun Religi.

Salura, Purnama. 2008. Menelusuri Arsitektur Masyarakat Sunda. Bandung: Cipta Sastra Salura.

Widagdho, Djoko. 2000. "Sikap Religius Pandangan Dunia Jawa" dalam Amin, Darori (Ed.). Islam dan Kebudayaan Jawa. Yogyakarta: Gama Media. 
Ibdg' Jurnal Kebudayaan Islam

Widyandini, Wita. 2013. "Pola Tata Ruang Permukiman Bonokeling di Banyumas". Tesis. Magister Teknik Arsitektur. Semarang: Universitas Diponegoro.

Yana, MH. 2010. Falsafah dan Pandangan Hidup Orang Jawa. Yogyakarta: Absolut. 